\title{
Sperm Motility and Viability in West African Dwarf Rams Treated with Euphorbia hirta
}

\author{
Motilidad y Viabilidad Espermática en Carneros Enanos \\ del Oeste Africano Tratados con Euphorbia hirta
}

"M. O. Oyeyemi; "** S. G. Olukole; "Bolanle Taiwo \& *Deborah A. Adeniji

OYEYEMI, M. O.; OLUKOLE, S. G.; TAIWO, BOLANLE \& ADENIJI, D. A. Sperm motility and viability in west african dwarf rams treated with Euphorbia hirta. Int. J. Morphol., 27(2):459-462, 2009.

SUMMARY: Four adult sexually matured and clinically healthy West African Dwarf (WAD) rams aged between 24 and 30 months were used for the study. The rams were first used as control and later as experimental animals upon being orally dosed with Euphorbia hirta extract at $400 \mathrm{mg} / \mathrm{kg}$ body weight for 14 days. Semen samples were collected from the rams a day after the administration of the plant extra and seven days after. The objective of the study was to investigate the effect of Euphorbia hirta on the semen picture of WAD rams. There were significantly differences $(\mathrm{P}<0.05)$ in the semen picture as reflected in a reduction of sperm motility from $80 \%$ to $47.5 \%$ and live-dead ratio from $90.75 \%$ to $32.5 \%$ in the control and post-experimental stages of the study respectively. This indicates that the fertilization capacity and livability of spermatozoa were negatively affected. There were no significant differences in the values of body parameters measured across the stages of the study. The plant is therefore not recommended for medicinal purpose in male animals.

KEY WORDS: Sperm motility; Ram; Viability; Euphorbia hirta.

\section{INTRODUCTION}

Euphorbia hirta (Asthma weed) is an important herb growing up to $40 \mathrm{~cm}$ tall, occupying open waste spaces, roadsides and gardens in the West African sub-region (Burkhill, 1994). Containing relatively abundant white latex, the plant has been reported to have tannis, gallic acid, quercetin, phenols, phyto-sterols, alcohol and alkaloids (Kerharo \& Adams, 1974). The West African Dwarf rams are relatively light sheep weighing between 25 and $45 \mathrm{~kg}$, widely distributed throughout the humid and sub- humid areas of West Africa (Charray et al., 1992). Rams are exclusively kept for meat, and are also economically important because of their attachment to the Muslim faith.

Notable anatomical features of external genitatia of rams are well developed pendulous scrotum covered with wool and a palpable penis of about $4 \mathrm{~cm}$ long (Jainudeen \& Hafez, 1982). Sperm production in rams has been estimated at about 20 million sperm per gram per testis (Knight, 1977). Sperm output in rams is directly proportional to testicular size and a ram possessing large symmetrical testes free from defeats is likely to produce semen of good quality (Kilgour, 1979).
Infertility in rams has been traced to seasonal factors, immaturity, oligospermia resulting from infection, malnutrition and high environmental temperature (Rathore, 1968). The semen of the ram is creamy white, 0.3 to $1.0 \mathrm{ml}$ in volume with normal concentration varying from $1.6 \times 10^{9}$ to $6.0 \times 10 \mathrm{x}^{9}$ per ml with an average of $3.6 \times 10^{9}$ per ml (Moss et al., 1988).

This study was aimed at investigating the effect of Euphorbia hirta on the semen picture of the West African Dwarf rams.

\section{MATERIAL AND METHOD}

Animal protocol. Four sexually matured West African Dwarf (WAD) rams, weighing between 11 and $20 \mathrm{~kg}$, were used for the study. They were kept at the Large Animals Ward II of the Veterinary Teaching Hospital (VTH), University of Ibadan, located between latitude $150 \mathrm{~N}$ and $300 \mathrm{~S}$ with relative humidity

\footnotetext{
${ }^{*}$ Department of Veterinary Surgery and Reproduction, University of Ibadan, Nigeria.

** Department of Veterinary Anatomy, University of Ibadan, Nigeria.
} 
ranging from $50-80 \%$, rainfall is about 70 inches per annum and temperature between $28^{\circ} \mathrm{C}$ and $34^{\circ} \mathrm{C}$.

The animals were kept on guinea corn offal and grasses, water was provided ad libitum. The animals were dewormed using Albendazole and Levamisole while Ivomec was used to control ectoparasites and mange. They were vaccinated against pestes petit ruminants (PPR) using PPR vaccine (NVRI, Vom) among other veterinary attentions.

Plant source and administration of extract. Euphorbia hirta was collected from the University of Ibadan Community. The leaves were removed and processed into aqueous solution by blending $100 \mathrm{~g}$ of leaves in $500 \mathrm{ml}$ of distilled water and then filtered. The filtrate was administered orally at a daily dose of $400 \mathrm{mg} / \mathrm{kg}$ body weight for 14 days using a bottle.

Body parameters. The weight of the animals in each case was determined using Microvar® weighing machine, while the flexible tape rule was used to measure the scrotal length and circumference, crown rump length, whither's height and chest circumference.

Semen collection. Semen was collected from the rams a day after the administration of the plant extract and also 7 days after, using the electroejaculation method as described by Oladejo (2000).

Morphological studies. On a clean, warm glass slide, a drop of semen was placed as well as two drops of Wells and Awa stain. The semen and stain were thoroughly mixed together with a smear made on another clean and warm slide. The smear was air-dried and observed using the light microscope starting with low power to high magnification. The presence of abnormal cells out of at least 400 sperm cells from several fields on the slide was counted and their total percentage estimated.

Sperm motility. Sperm motility was assessed by the method described by Zemjanis (1977) and was evaluated microscopically within 2-4 minutes of their isolation from the cauda epididymis and later expressed as percentages.

Sperm count. Epididymal sperm count was obtained by mincing the four pairs of cauda epididymis in distilled water and filtering through a nylon mesh. The spermatozoa were counted by haemocytometer using improved Neubauer (Deep 1/10mm, LABART, Germany) chamber described by Pant \& Srivastava (2003).

Sperm live/dead ratio. A drop of semen was placed in $1 \%$ eosin and 5\% nigrosine in 3\% sodium citrate dehydrate solution for the live/dead ratio as described by Wells \& Awa (1970).
Statistical analysis. Paired comparisons were done using the " $t$ " test where applicable. Analysis of variance was used where means was significantly differed; separation of means was also done using Duncan's multiple range test (Steel \& Torrie, 1980).

\section{RESULTS}

The values for body parameters of the WAD rams at different stages of the work are presented in Table I. The effects of Euphorbia hirta on sperm mass activity, motility live/dead ratio (\%), colour, volume and counts are given in Table II. The colour of the ejaculate for the control, experiment (period of administration of the plant extract) as well as the post experiment period varied between creamy and milk. The percentage sperm motility for the experiment $(72.5 \%)$ was significantly higher $(\mathrm{P}<0.05)$ than the postexperiment value $(47.5 \%)$. The percentage motility for the control $(83.0 \%)$ was higher than that of the experiment (72.5\%). The live/dead ratio for the experiment $(81.25 \%)$ expressed in percentage livability was significantly higher $(\mathrm{P}<0.05)$ than the post-experiment value of $32.5 \%$. The experiment value was however significantly lower $(\mathrm{P}<0.05)$ than the control value $(90.75 \%)$.

\section{DISCUSSION}

Throughout the 3 stages of this work, the colour of ejaculate obtained varied between milk and cream. It implies that Euphorbia hirta does not affect the colour of semen. There was no significant difference $(\mathrm{P}<0.05)$ in the volume of the ejaculate across the stages of the work. Nevertheless, there were slight increases in the volume of ejaculate obtained as the work progressed from the control to the postexperiment stage of the work (Table II). Nutrition and or environmental factors could have been responsible for these slight increases. The volume obtained is similar to that of earlier reports on the WAD bucks (Ajala et al., 2001). There was a positive correlation between the weights of the rams and the volume of ejaculate obtained in the work. There was no significantly difference $(\mathrm{P}<0.05)$ in the mass activity of semen across the different stages of the work. This is similar to the effect of the pumpkin plant on the mass activity of semen of WAD bucks as reported by Oyeyemi et al., (2000). There were no significant differences in weight, scrotal length, scrotal circumference, crown rump length, whither's height and chest height for the different stages of the work (Table I). This is similar to the report of Oyeyemi et al., on body parameters in WAD bucks treated with the pumpkin plant. 
Table I. Measurement of body parameters.

\begin{tabular}{|c|c|c|c|c|c|c|c|}
\hline Control & $\mathbf{S} / \mathbf{N}$ & BW (Kg) & SL $(\mathrm{Cm})$ & $\mathrm{SC}(\mathrm{Cm})$ & CRL (Cm) & WH (Cm) & $\mathrm{CC}(\mathrm{Cm})$ \\
\hline & $\mathrm{K} 1$ & 19.6 & 14.0 & 23.8 & 68.5 & 54.1 & 68.0 \\
\hline & $\mathrm{K} 2$ & 12.0 & 17.2 & 20.2 & 69.1 & 47.5 & 51.5 \\
\hline & $\mathrm{K} 3$ & 15.2 & 12.8 & 22.4 & 73.2 & 47.0 & 61.5 \\
\hline & $\mathrm{K} 4$ & 16.0 & 13.0 & 21.5 & 85.2 & 63.0 & 62.2 \\
\hline \multicolumn{8}{|c|}{ Experiment } \\
\hline & $\mathrm{K} 1$ & 20.2 & 13.5 & 25.0 & 80.0 & 61.0 & 63.0 \\
\hline & $\mathrm{K} 2$ & 11.8 & 12.5 & 22.5 & 75.5 & 47.5 & 53.0 \\
\hline & K3 & 15.4 & 15.0 & 22.0 & 74.5 & 50.0 & 59.0 \\
\hline & $\mathrm{K} 4$ & 16.0 & 13.0 & 21.0 & 91.0 & 63.0 & 63.0 \\
\hline \multicolumn{8}{|c|}{ Post experiment } \\
\hline & $\mathrm{K} 1$ & 19.2 & 16.0 & 25.5 & 80.0 & 55.9 & 62.0 \\
\hline & $\mathrm{K} 2$ & 11.0 & 13.5 & 21.0 & 69.0 & 46.0 & 50.0 \\
\hline & K3 & 15.4 & 15.5 & 25.0 & 77.5 & 48.5 & 60.0 \\
\hline & K4 & 13.6 & 13.0 & 22.0 & 79.0 & 62.0 & 59.0 \\
\hline
\end{tabular}

BW: Body weight, SL: Scrotal length, SC: Scrotal circumference, CRL: Crown rump length, WH: Whither's height, CH: Chest circumference, K: Animal.

Table II. Semen characteristics at different stages.

\begin{tabular}{|c|c|c|c|c|c|c|c|}
\hline Control & $\mathbf{S} / \mathbf{N}$ & $\begin{array}{c}\text { Mass } \\
\text { Activity }\end{array}$ & Motility & Live/Dead Ratio (\%) & Colour & $\begin{array}{c}\text { Volume } \\
\text { (MI) }\end{array}$ & Count \\
\hline & K1 & +++ & 80 & 90 & Creamy & 0.5 & 92 \\
\hline & $\mathrm{K} 2$ & + & 75 & 85 & Milky & 0.05 & 112 \\
\hline & K3 & + & 82 & 90 & Milky & 0.1 & 109 \\
\hline & K4 & +++ & 95 & 98 & Creamy & 0.3 & 123 \\
\hline & Total & & 332 & 363 & & 0.85 & 325 \\
\hline & Average & ++ & 83 & 90.75 & Creamy & 0.21 & 81.25 \\
\hline \multirow[t]{7}{*}{ Experiment } & & & & & & ) & \\
\hline & K1 & ++ & 70 & 80 & Milky & 0.3 & 102 \\
\hline & $\mathrm{K} 2$ & +++ & 90 & 95 & Milky & 0.2 & 124 \\
\hline & K3 & ++ & 70 & 80 & Milky & 0.1 & 94 \\
\hline & K4 & +++ & 60 & 70 & Creamy & 0.5 & 144 \\
\hline & Total & & 290 & 325 & & 1.1 & 464 \\
\hline & Average & ++ & 72.5 & 81.25 & Milky & 0.28 & 116 \\
\hline \multicolumn{8}{|c|}{ Post experiment } \\
\hline & K1 & +++ & 40 & 20 & Creamy & 0.8 & 171 \\
\hline & $\mathrm{K} 2$ & ++ & 60 & 30 & Milky & 0.2 & 249 \\
\hline & K3 & +++ & 30 & 20 & Opalescent & 0.3 & 20 \\
\hline & K4 & +++ & 60 & 60 & Milky & 0.5 & 173 \\
\hline & Total & & 190 & 130 & & 1.8 & 613 \\
\hline & Average & +++ & 47.5 & 32.5 & Milky & 0.45 & $153.25 \mathrm{e}$ \\
\hline
\end{tabular}

The semen characteristics observed in the study showed that the percentage motility of the control experiment (83.0\%) was higher than $80 \%$ reported by Garner \& Hafez (1982). This is not a significant difference and could have been due to nutrition, age and environmental factors. The value of the percentage sperm motility for the post-experiment (47.5\%) was however, lower than the minimal value of $60 \%$ reported by Garmer \& Hafez and differed significantly $(\mathrm{P}<0.05)$ with 
the experimental value of $72.5 \%$. This indicates that the plant has a negative effect on sperm motility.

The number of dead spermatozoa increased significantly, $(\mathrm{P}<0.05)$ from the control stage down to the post administration stage of the work. This was markedly observed as the percentage livability of sperm cells for the post-experiment $(32.5 \%)$ was lower than the control value of $90.75 \%$ (Table II). This is lower than the $96.57 \%$ obtained in WAD bucks on percentage livability of sperm cells as reported by Oyeyemi et al., and therefore reveals that Euphorbia hirta has an adverse effect on the livability of sperm cells.

It can be concluded that Euphorbia hirta can induce oligospermia in animals having significantly $(\mathrm{P}<0.05)$ reduced sperm motility and percentage livability of sperms in the study. The plant can reduce fertility in male animals and is therefore not recommended for medicinal purpose in male animals especially those used for breeding purposes.

OYEYEMI, M. O.; OLUKOLE, S. G.; TAIWO, BOLANLE \& ADENIJI, D. A. Motilidad y viabilidad espermática en carneros enanos del Oeste Africano tratados con Euphorbia hirta. Int. J. Morphol., 27(2):459-462, 2009.

RESUMEN: Cuatro carneros enanos adultos de África Occidental sexualmente maduros y clínicamente sanos, con edades comprendidas entre los 24 y 30 meses, fueron utilizados para este estudio. Los carneros fueron utilizados como control y, más tarde, como animales de experimentación al ser medicados por vía oral con extracto de Euphorbia hirta en 400mg/kg peso corporal durante 14 días. Se recogieron muestras de semen de los carneros un día después de la administración de la planta y siete días después. El objetivo del estudio fue investigar el efecto de Euphorbia hirta en las imágenes de esperma de carneros enanos África Occidental. Hubo diferencias significativas $(\mathrm{P}<0,05)$ en la imagen del semen como reflejo de una reducción de la motilidad espermática del $80 \%$ al $47,5 \%$ y un ratio de vivos-muertos de $90,75 \%$ a $32,5 \%$ en la etapa control y después de las fases experimentales del estudio, respectivamente. Esto indica que la capacidad de fertilización y calidad de vida de los espermatozoides fueron afectados negativamente. No hubo diferencias significativas en los valores de los parámetros corporales medidos a través de las etapas del estudio. La planta por tanto no es recomendable para fines medicinales en los animales machos.

\section{PALABRAS CLAVE: Motilidad espermatica; Carnero; Viabilidad; Euphorbia hirta.}

\section{REFERENCES}

Ajala, O. O.; Oyeyemi, M. O.; Akusu, M. O. \& Eimunjeze, H. E. The effects of scrotal insulation on the testicles and spermatozoa characteristics of West African Dwarf Goats. Sokoto J. of Veterinary Sciences, 3(1):44-50, 2001.

Burkhill, H. M. The useful plant of West Africa. Kew, Royal Botanic Gardens, 1994. pp.21 -250.

Charray J.; Humbert, J. M. \& Levif, J. Manual of sheep production in the humid tropics of Africa. Wallingford, CAB International, 1992. p.187.

Garner, D. L. \& Hafez, E. S. E. Spermatozoa and seminal plasma. In: Reproduction in farm animals. (Ed) E.S.A. Hafez. Philadelphia, Lea and Febriger, 1982. pp.12-7.

Jainudeen, M. R. \& Hafez, E. S. E. In Reproduction in farm animals. (Ed) E.S.E. Hafez. Philadelphia, Lea and Febriger, 1982. pp.11224.

Kerharo J. \& Adam J. G. La Pharmacopée Sénégalaise. Traditionnelle, Plantes Médicinales et Toxiques. Paris, Edition Vigot-Frères, 1974. pp.9-12.

Kilgour R. J. The importance of the ram on flock fertility. Wool Technology and Sheep Breeding, 27:41-4, 1979.

Knight, T. W. Methods for indirect estimation of testes weight and sperm numbers in Merino and Romney rams. New Zealand J. Agric.Res., 20:291-6, 1977.
Moss, T. A.; Melrose, D. R.; Reed, H. C. B. \& Vendeplasche, M. Spermatozoa, semen and artificial insemination. In: J.A. Laing (Ed) W.J. Brinley Morgan. Fertility and infertility in domestic animals. 4th ed. London, Balliere Tindall, 1988. pp.132-54.

Oyeyemi, M. O.; Akusu, M. O.; \& Ola-Davies, O. Effect of successive ejaculations on the spermiogram of West African dwarf goats (Capra Hircus L). Vet. arhiv., 70(4):215-21, 2000.

Pant, N. \& Srivastava, S. P. Testicular and spermatotoxic effects of quinalphos in rats. J. Appl. Toxicol., 23(4):271-4, 2003.

Rathore, A. K. Effects of high temperature on sperm morphology and subsequent fertility in Merino sheep. Proc. Austr. Soc. anim. Prod. 7:270-4, 1968.

Steel, R. C. D. \& Torrie, G. H. Principles and procedures of statistics. A Biometric Approach. $2^{\text {nd }}$ ed. New York, McGraw-Hill Books, 1980. pp.17-23.

Wells, M. E. \& Awa, O. A. New technique for assessing acrosomal characteristics of spermatozoa. J. Dairy Sci., 53(2):227-32, 1970.

Zemjanis, R. Diagnostic and Therapeutic technique in Animal Reproduction. Baltimore, Williams and Wikins Company, 1977. pp. 88-96.

Correspondence to:

Dr S. G. Olukole

Department of Veterinary Anatomy

University of Ibadan, NIGERIA

E-mail:deborolukole@yahoo.com

Received: 29-09-2008

Accepted: 22-12-2008 